\title{
Wage and occupational assimilation by skill level: migration policy lessons from Spain
}

Núria Rodríguez-Planas

Correspondence:

rodriguez-planas@iza.org

IZA, Bonn, and IAE-CSIC, Barcelona,

Spain

\begin{abstract}
What are the migration policy lessons that can be learned from the Spanish case? Unlike countries with a large tradition of receiving immigrants, in Spain having a high-school degree does not give immigrants an advantage in terms wage or occupational assimilation (relative to their native counterparts). This paper discusses the potential explanations behind this result and analyzes the consequences of this result in terms of migration policy recommendations.
\end{abstract}

JEL codes: J15, J24, J61, J62

Keywords: Wage assimilation, Occupational assimilation, Education, Migration policy

\section{Introduction}

Much of the literature on immigrants' assimilation has focused on countries with a long tradition of receiving immigrants ${ }^{1}$. Most of these studies find that after an initial adaptation period, immigrants' earnings and employment choices converge towards those of similar natives. Moreover, the evidence shows that assimilation is directly related with immigrants' skill level. In contrast, not much is known on how immigrants adjust to an economy with little experience as a host country. Nonetheless understanding immigrants' assimilation process in such circumstances can be of most policy relevance, especially in the midst of the new immigration flows towards countries other than the most traditional countries receiving immigrants. Indeed Southern European countries have recently experienced a preponderance of migrants in their territory (Reher and Silvestre, 2009).

In this paper, we propose to use Spain as a quite unique experience to analyze such issues as the country experienced an unprecedented immigration boom in a short period of time-with immigrants representing from 1\% of the population in 1990 to $12 \%$ in 2009. Given the impressive inflow of immigrants that Spain has experienced in the last ten years (on average, an annual flow of immigrants of 500,000 per year), the assimilation process of immigrants is an important issue not only for economic, but also for social reasons. Moreover, the experience of Spain ought to be of interest to policymakers of other Southern European countries that share common cultural affinities (such as, the strong family-orientated values associated with a low degree of individualization-Flaquer, 2000); similar socio-economic circumstances (such as, rigid labor and financial markets, important underground economy, low productivity

(C) 2012 Rodríguez-Planas; licensee Springer. This is an Open Access article distributed under the terms of the Creative Commons Attribution License (http://creativecommons.org/licenses/by/2.0), which permits unrestricted use, distribution, and reproduction in any medium, provided the original work is properly cited. 
growth, and excessive borrowing - Garicano, 2008; Andrés, 2009; de la Rica, 2009; Estrada et al., 2009; and Cuñat and Garicano, 2009); welfare commonalities (such as, the mix of universalistic health-care and education systems with professional pension schemes, the high degree of institutional fragmentation, and the lack of an explicit family policy as evidenced by a very limited number of family-friendly social provisions-Guillén, 1997; Ferrera, 1996; Rodríguez-Planas, 2012); and a recent preponderance of illegal migration and weak governmental capacity to regulate immigrants' inflows-Castles and Miller, 2003; Arango, 2004; Solé, 2004; Martin et al., 2006).

Unlike the findings from countries with a long tradition of receiving immigrants (summarized in Section 2), Section 3 of this paper presents evidence that skilled immigrants in Spain do not assimilate as well as low-skilled ones. It is important to note that we are not the first to find evidence that in Spain the recent wave of immigrants has suffered from over-education. One of the first studies to explore this question is that of Amuedo-Dorantes and de la Rica, 2007. Using 2001 decennial Population Census data, these authors find evidence of immigrants' progressive employment and occupational mobility as their residence in Spain increases. Unfortunately, due to data limitations, their analysis focuses on immigrants who arrived during the second half of the 1990s and, therefore, misses most of the massive recent inflow of immigrants ${ }^{2}$. Using crosssectional data from the 1996 to 2005 Spanish Labor Force Survey, Fernández and Ortega 2008, find that although the Spanish labor market is able to absorb immigrants within 5 years after arrival, it does so at the expense of allocating them in fixed-term contract jobs for which they are over-qualified. Similarly, Sanromá et al. 2009, find that non-EU15 immigrants in Spain suffer over-education, in both incidence and intensity, and that the process of assimilation is very low. Using panel data from Social Security records, Izquierdo et al., 2009, find that, despite a sizeable and significant wage gap reduction between legal immigrant men working in wage and salary jobs in the formal sector and their native counterparts within the 5 years after arrival to Spain, full assimilation of wages does not take place as a 15 percentage points wage differential remains. The novelty of the current paper is that by doing the analysis by skill level an interesting new insight emerges, namely that having a high-school degree does not give immigrants an advantage in terms occupational or wage assimilation (relative to their native counterparts). After exploring the potential reasons behind this result in Section 4, this paper concludes with a discussion of the policy consequences for the Spanish case.

\section{Skilled versus unskilled migration?}

Many countries prioritize skill-based immigration because much evidence shows that the migrant-native wage gap is smallest for the highest skilled workers upon arrival and convergence increases with immigrants' educational level. Similarly, studies analyzing the occupational adaptation of immigrants usually finds that assimilation is directly related with immigrants' skill level.

For instance, in the 1980s and early 1990s in Canada where the immigration point system was used to select migrants based on their education and experience, Green, 1999, finds that male immigrants undergo a rapid adjustment within the first 3 years after arrival, moving first into and then out of non-employment and less skilled jobs and toward the more skilled occupations indicated in their original intentions during the skill assessment. While Green finds little evidence of immigrant men being 
underrepresented in more skilled occupations relative to native-born workers with similar education and experience characteristics; he does find that those male immigrants who did not undergo a skill assessment when they entered Canada or were not fluent in English or French were much more likely to be in low-skilled occupations and to be less mobile over time (relative to their native counterparts) ${ }^{3}$.

Similarly, Borjas, 1992, examines data on several immigrant attributes, including occupation in the United States using the 1940, 1960, 1970, and 1980 Censuses. He finds that, in the 1970 Census, immigrants arriving in the previous 5 years were more likely to be in managerial and professional, service, and laborer jobs relative to the native born, and that they were under-represented in "precision production, craft and repair" jobs and in the primary sector. However, he finds that, by 1980, the most recent immigrants were no longer over-represented in managerial and professional jobs but instead they were slightly over-represented in primary and farming jobs. Similar results have been found by Card and Dinardo, 2000; and Card, 2005. These authors explain that this shift in the composition of immigrants is to a large extent explained by US immigration policy, which went from establishing national origin quotas with a strong bias in favor of Northern Europeans prior to 1965, to establishing preferences for people with family members already in the country ${ }^{4}$.

Overall research from countries with a long tradition of receiving migrants finds that assimilation is directly related with immigrants' skill level. Bauer and Zimmermann, 1999, find that migrants with higher skill levels face sharper deteriorations in their relative labor market position at the time of immigration to Germany, but are also able to reach their original occupational status much faster than low-skilled immigrants. Recently, Toussaint-Comean 2006, has analyzed the occupational assimilation of Hispanic immigrants in the US using panel data and has found that the degree of assimilation is higher for those with at least some college education-while for those with a highschool degree or less convergence is modest at most.

A related issue in this literature is the imperfect portability of human capital (acquired abroad) and the relevance of the national origin of an individual's education and experience in determining the individual's value in the labor market. Using data from Israel, Friedberg, 2000, demonstrates that the most important factor determining the gap in the standard human-capital-corrected earnings of immigrants and natives is the source of their human capital. She finds that human capital is imperfectly portable, and that the national origin of an individual's education and experience is a crucial determinant of her value in the labor market. Similarly, Greenand Worswick, 2002, find zero returns to foreign experience for recent immigrant cohorts but show that, in Canada's case, this is a change from the early 1980 s when immigrants earned returns to foreign experience that were similar to what the native born were earning for domestically acquired experience. Again, much of this change over time is related to changes in the source country composition of the inflow. More recently, similar results are found for immigrant women in Canada (Wanner and Ambrose, 2003) and the United States (Ozden and Neagu 2007). Moving to Europe, Hartog and Zorlu, 2009, recently found that higher education acquired at home for refugees in The Netherlands did not generally pay off during the first five years in the Dutch labor market. In Spain, Sanromá et al. 2009, analyze the difference in returns to human capital acquired abroad for both immigrant men and women and find that the degree of transferability depends on the 
geographic origin, as transferability is greater for countries that are highly developed or have a similar culture or language, and lower for developing and those with more distant cultures.

While most of the assimilation literature focuses on males, papers on women migrants are relatively scarce. One of the reasons for this is that most of the analysis on assimilation does not study joint labor market participation and performance decisions, even though the participation decision is endogenous. Ozden and Neagu 2007, are among the few papers to address this issue by analyzing jointly immigrant women's participation and performance in the U.S. labor market. Overall, most of the assimilation results found for men hold for immigrant women-Schoeni, 1998; Cobb-Clark, 1993; and Ozden and Neagu 2007. However, as Boyd 1984, 1992, explains, immigrant women face entry into a labor market that penalizes them twice because of their immigrant status and their gender. In addition, this author points out that, with the demands placed on women for work in the home, employment in the labor market represents a double burden that may prevent many immigrant women from learning the language of the host country, and hence condemning them to the ethnic employment niches. As such, Lindley, et al., 2006, find that women born overseas who arrived as adults to the UK were 16 percentage points less likely to be employed than their native counterparts even 5 years after arrival.

An interesting pattern of "family investment strategy" among low-skilled European women immigrating to Canada prior to 1973 and among women immigrating in the US seems to emerge. Indeed, several authors have found that, in those countries, the earnings of immigrant women are higher than those of native women around the time of migration in the U.S and Canada-Long, 1980; Beach and Worswick, 1993; Baker and Benjamin, 1994 and Baker and Benjamin, 1997; Wanner and Ambrose, 2003; and Ozden and Neagu 2007. These authors suggest that these immigrant women work harder than their native counterparts to help their families become established in the host country and to assist their husbands in obtaining language skills and credentials before they themselves entered the host country labor market.

\section{The Spanish case}

At least four reasons explain the Spanish immigration boom, which changed the composition of migrants in Spain over time, with EU-15 migrants losing weight over South Americans and migrants from the EU-enlargement countries. First, Spanish booming economy and the social promotion-in the form of increased education levels and higher labor force participation-of its national (especially female) population generated a demand for foreign workers (Carrasco et al. 2008a, b; and Farré et al., 2011). Second, its physical proximity to northern Africa and Eastern Europe places Spain close to countries that supply immigrants. Third, its shared language and historical pass with Latin Americans facilitates the social and cultural assimilation of immigrants from this continent, as illustrated by the fact that close to $50 \%$ of the immigrants are from Latin America. Finally, Spanish weak governmental capacity to regulate immigrants' inflows and several generous amnesties that have granted legal residence to illegal immigrants have de facto converted Spain in an immigrant friendly country (Dolado and Vázquez, 2007; Izquierdo et al., 2009, among others). 
Spain has not had an active policy of attracting immigrants. As early as 1985, Spain imposed severe restrictions on non-European Union foreigners who wanted to establish Spanish residency and citizenship ${ }^{5}$. Beginning 1993, further tightening took place with tougher restrictions on work and residency permit renewals and the implementation of immigration quotas system, which limited the entry of foreigners to about 30,000 immigrants per year. At the turn of the century, Spain updated its immigration legislation and assimilated it to that of other European countries. However, the free-entrance of foreigners as tourists together with a lax implementation of immigration laws and several generous amnesties that have granted legal residence to illegal immigrants (1985, 1991, 1996, 2000, 2001, and 2005) have converted Spain in an attractive destination for immigrants. In fact, the most common way of obtaining legal status in Spain during the past two decades has been through amnesties. Most frequently immigrants arrived in Spain either illegally or as tourists, and they were subsequently granted legal status through the multiple amnesties - see Amuedo-Dorantes and de la Rica, 2005, 2007, Dolado and Vázquez 2007, and Izquierdo et al., 20096. Between 1985 and 1991, as many as 150,000 immigrants regularized their status; between 1996 and 2001, a total of 400,000 immigrants did the same; and in the last amnesty, that of 2005, as many as 550,000 immigrants got their residence permits.

\section{Occupational assimilation analysis by skill level}

Using cross-sectional data from second quarter of the Spanish Labor Force Survey (LFS) from the years 2000 to 2008 and focusing on individuals between 19 and 65 years old, we first analyze the occupational assimilation of immigrants using a synthetic cohort analysis as in Green $1999^{7,8}$. Immigrants are defined as foreign-born workers who do not have the Spanish nationality. One of the strength of the LFS is that it is supposed to include both legal and illegal immigrants, in contrast with alternative datasets that only cover legal ones, such as the data from data from Social Security Records or the Wage Survey Structure. That said, the potential under-reporting of illegal immigrants is likely (as the LFS is voluntary, in contrast with the Census, which is mandatory) especially before an amnesty. Similarly, return migration related (or not) to an amnesty may also be worrisome, as both return migration and under-reporting of immigrants may generate deterministic biases in our analysis. Sensitivity analysis suggest that amnesties ought not to be a major concern in our analysis-similar results are found by Amuedo-Dorantes and de la Rica, 2007; and Fernández and Ortega $2008^{9}$.

Figure 1 shows the occupational distribution changes with time since arrival in Spain for a given cohort of migrants relative to observationally equivalent natives. More specifically it plots the net assimilation effect, which compares the changes in the different occupational choices over time for a given immigrant (synthetic) cohort to the changes for comparable natives, assuming that immigrants and natives experience change in the economy in the same way. Panel A shows the analysis for males and by education level, and panel $\mathrm{B}$ for females ${ }^{10}{ }^{11}$. The occupational choices are the following five choices: "Not working", "Non-qualified", "Qualified blue-collar", "Other white-collar" and "Professional" occupations. Our methodological approach captures the participation decision by including the "Not working" category, which includes both the unemployed and persons out of the labor force, as one of the possible occupational choices. This approach resembles 


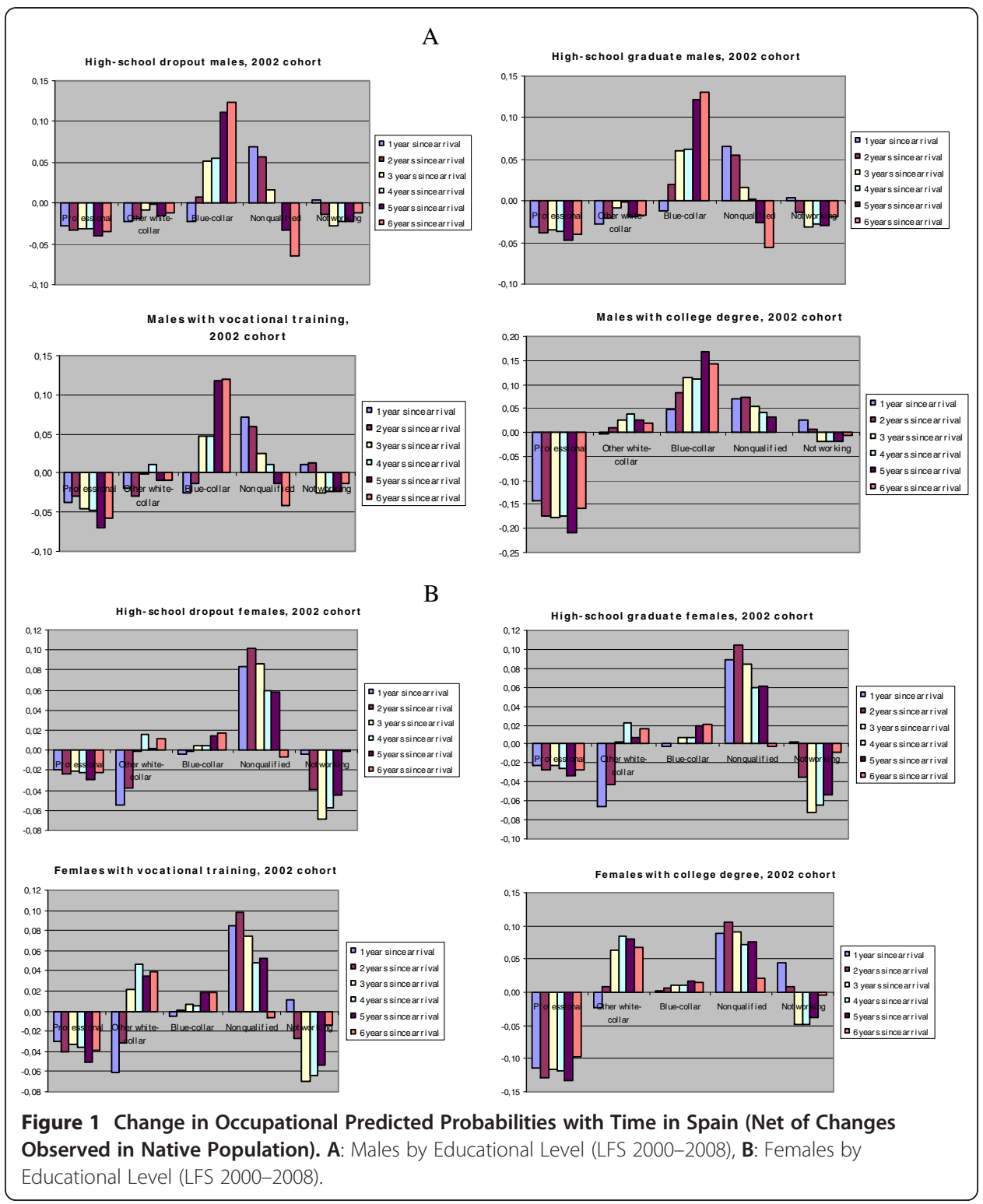

that of Lindley et al., 2006, who use a behavioral model for the choice of whether to take paid work for ethnic women in the United Kingdom ${ }^{12}$.

A positive estimate implies that there is an over-representation for a particular cohort of immigrants in a given occupation category compared to that same cohort $k$ years earlier (net of the changes that have occurred within that same period among the natives). For instance, in the top LHS panel of Figure 1A, the sixth bar height in the "blue-collar" category indicates that immigrant men without a high-school degree who arrived in Spain in 2002 are 13 percentage points more likely to hold a job in a "qualified blue-collar" occupation in 2008 than in 2002 when they first arrived, relative to the change observed over the same period in the same occupational category among their natives counterparts. The main findings are summarized below.

For immigrant men without a high-school degree, the patterns observed in the "nonqualified" and "qualified blue-collar" categories in the top LHS chart of Figure 1A suggest 
an assimilation effect as recently arrived immigrants adjust to the new economy. Within the first few years after arrival, immigrants without a high-school degree first move from "not working" to "non-qualified" jobs (as shown by the positive estimates for the "non-qualified" category and the negative estimates for the "non-working" category). However, after 3 to 4 years after arrival, they begin to shift out of "non-qualified" jobs towards "qualified bluecollar" occupations.

A very similar assimilation pattern is observed for male workers with a high-school degree (as shown in the top RHS chart of Figure 1A). The differences across these two education groups are practically inexistent, suggesting that having a high-school degree does not give immigrants an advantage in terms of the process of assimilation in Spain nor the occupations where they end up working in $^{13}$.

The assimilation pattern of low-skilled female immigrants--shown in Figure 1B-is similar to that of men as they also move from the "not working" categories into the "non-qualified" category during the first years after arrival. And we also observe some "catching up" into the "other white-collar" category for these women.

Moving now to higher-skill workers, it comes as a surprise that the pattern of occupational assimilation of immigrant men with vocational training is strikingly similar to the pattern observed for immigrant men with no high-school degree--shown in the bottom LHS panel of Figure 1A. Immigrant men with vocational training shift into "non-qualified" occupations during the first couple of years after arrival, and it is not until the third year after arrival that they move into "qualified blue-collar" occupations. A similar pattern is observed for immigrant men with a college degree, although their speed of assimilation towards "qualified blue-collar" jobs takes place right at arrival and is faster as time in the host country increases ${ }^{14}$.

For immigrant women having a vocational degree or a university degree seems to help in that some assimilation towards the "other-white collar" occupations seems to take place 3 years after arrival. However, the persistent large flows out of "non work" into "non-qualified" occupations (even after 5 years in the host country) reflects that many of these low-skilled immigrant women are relegated to domestic services or nursing-home care (Farré et al,, 2011). Finally, some evidence of "family investment strategy" is observed among immigrant women in Spain as they are much more likely to be working than their native counterparts. The only exception to this is for women immigrant with a university degree who are overrepresented in the non-working category.

There are very few differences in the assimilation process of Latin American and Eastern Europeans immigrants (estimates shown in Alcobendas et al., 2012), suggesting that language has little effect in terms of speeding assimilations. Perhaps worth highlighting is that African high-school dropouts' shift out of the "non-qualified" category and into the "qualified blue-collar" category takes longer than that observed for other immigrants without a college degree.

\section{Caveats from our labor force survey analysis}

At least two concerns emerge. First, our estimates may be biased due to the crosssectional nature of our data. Estimates from cross-sectional data may be biased if the quality of the different cohorts of immigrants changes over time. Even if the quality of the different cohorts does not change, synthetic cohort estimates may be biased if there is selective permanent out-migration and selective back-and-forth 
migration between the immigrants' host and home country. For example, several authors have found that a failure to adjust for emigration leads to an overestimation of the wage assimilation among migrants who actually remain in the country as the low-earnings immigrants are more likely to emigrate than high-earning ones-Edin et al., 2000; and Lubotsky, 2007. Although Constant and Massey, 2002, and Izquierdo et al., 2009, do not find evidence that cross-sectional data overestimates wage assimilation in Germany and Spain, respectively.

Second, occupational assimilation is not as standard in the literature as wage assimilation. Thus, it would be interesting to explore whether the earlier results suggesting that a high-school degree does not do much in terms migrants' occupational assimilation in Spain also holds when instead of occupational assimilation we study wage assimilation. As information on wages is not available in the Spanish LFS, we use the longitudinal Social Security data from the 2008 wave of the Continuous Sample of Working Histories (hereafter CSWH) to analyze wage assimilation between immigrants and similar natives by skill-level in the next sub-section.

\section{Wage assimilation analysis by skill level}

We follow Izquierdo et al., 2009, and restrict our sample to wage and salary workers who work full-time. As these authors do, we focus on men because we are concerned of potential sample selection bias among (native) women as they are more likely to move in and out of the labor market, and therefore may be lost in the $\mathrm{CSWH}^{15}$. An immigrant is a person who does not have Spanish nationality.

The paper uses daily wages that are computed as the ratio between monthly earnings and the days worked in a particular month. Experience is measured as years after the first entry in the labor market. We also estimate potential experience abroad for immigrants by removing from the age of entry in Spain, the potential age of entry in the labor market in the origin country, where potential age of entry in the labor market in the country of origin is 16 if the person does not have a university degree and 22 if the person has a university degree. For natives, the age of entry in Spain is the age of the person at the moment of the first Social Security contribution.

The only variable recording education in the CSWH comes from the Spanish Municipal Registry of Inhabitants and was last updated in 1996, which leads to important underestimates of true education-especially for natives relative to immigrants as the latter are much more likely to have registered their education in a later date. Because of this we use the CSWH's own classification of skills required to perform their job-assuming that if the immigrant (or native) has a job requiring a college degree, the employer has recognized such degree. Thus, the analysis is done separately for three different sub-populations: (1) those working in low-skilled jobs (not requiring a high-school degree); (2) those working in medium-skilled jobs (requiring a high-school degree); and (3) those working in high-skilled jobs (requiring a university degree ${ }^{16}$. The major difference between this dataset and the LFS is that now only individuals working in the formal sector and for a wage and salary job are included in the analysis.

Table 1 shows unconditional median daily wage differentials between migrants and natives by skill level as a function of the time spent in Spain by migrants. Since the average migrant entered in Spain at age 25 to 30 years old and with 12 years of experience, a comparable native at $\mathrm{t}=0$ is someone with 12 years of experience. We choose 
Table 1 Median wages, males by educational level, 2008 MCVL

\begin{tabular}{|c|c|c|c|c|c|}
\hline & \multirow{3}{*}{$\begin{array}{l}\frac{\text { Spaniards }}{1979-1982} \\
€ / \text { day }\end{array}$} & \multicolumn{4}{|c|}{ no UE-15 } \\
\hline & & \multicolumn{2}{|c|}{ 1991-1995 } & \multicolumn{2}{|c|}{$2001-2005$} \\
\hline & & $€ /$ day & Differential & $€ /$ day & Differential \\
\hline \multicolumn{6}{|c|}{ High school drop outs } \\
\hline 0 & 45,7 & 29,6 & $-35,3 \%$ & 33,4 & $-26,9 \%$ \\
\hline 1 & 47,6 & 30,5 & $-36,0 \%$ & 34,9 & $-26,6 \%$ \\
\hline 2 & 48,5 & 31,1 & $-35,8 \%$ & 36,3 & $-25,2 \%$ \\
\hline 3 & 49,4 & 31,7 & $-35,7 \%$ & 37,0 & $-25,2 \%$ \\
\hline 4 & 49,4 & 32,7 & $-33,8 \%$ & 38,1 & $-22,9 \%$ \\
\hline 5 & 50,6 & 33,7 & $-33,3 \%$ & & \\
\hline 6 & 51,4 & 35,0 & $-32,0 \%$ & & \\
\hline 7 & 52,3 & 34,9 & $-33,3 \%$ & & \\
\hline 8 & 53,6 & 36,0 & $-32,9 \%$ & & \\
\hline 9 & 54,8 & 37,4 & $-31,7 \%$ & & \\
\hline 10 & 55,3 & 37,5 & $-32,2 \%$ & & \\
\hline \multicolumn{6}{|c|}{ High school graduates } \\
\hline 0 & 52,42 & 32,0 & $-38,88 \%$ & 33,4 & $-36,19 \%$ \\
\hline 1 & 54,64 & 31,7 & $-41,97 \%$ & 35,4 & $-35,29 \%$ \\
\hline 2 & 55,97 & 31,9 & $-42,98 \%$ & 37,1 & $-33,71 \%$ \\
\hline 3 & 57,83 & 33,1 & $-42,80 \%$ & 37,8 & $-34,60 \%$ \\
\hline 4 & 60,88 & 35,7 & $-41,31 \%$ & 39,2 & $-35,66 \%$ \\
\hline 5 & 64,58 & 34,2 & $-47,03 \%$ & & \\
\hline 6 & 65,41 & 36,4 & $-44,39 \%$ & & \\
\hline 7 & 67,32 & 35,2 & $-47,65 \%$ & & \\
\hline 8 & 68,95 & 37,5 & $-45,61 \%$ & & \\
\hline 9 & 69,79 & 40,0 & $-42,74 \%$ & & \\
\hline 10 & 71,23 & 38,9 & $-45,45 \%$ & & \\
\hline \multicolumn{6}{|c|}{ University degree } \\
\hline 0 & 62,3 & 36,57 & $-41,28 \%$ & 32,8 & $-47,27 \%$ \\
\hline 1 & 67,2 & 37,22 & $-44,63 \%$ & 35,7 & $-46,89 \%$ \\
\hline 2 & 75,2 & 38,48 & $-48,85 \%$ & 37,0 & $-50,79 \%$ \\
\hline 3 & 82,0 & 31,44 & $-61,65 \%$ & 39,1 & $-52,34 \%$ \\
\hline 4 & 88,0 & 34,28 & $-61,03 \%$ & 42,4 & $-51,83 \%$ \\
\hline 5 & 88,5 & 47,51 & $-46,29 \%$ & & \\
\hline 6 & 89,5 & 43,09 & $-51,85 \%$ & & \\
\hline 7 & 92,1 & 47,18 & $-48,75 \%$ & & \\
\hline 8 & 95,6 & 40,86 & $-57,24 \%$ & & \\
\hline 9 & 95,5 & 42,45 & $-55,54 \%$ & & \\
\hline 10 & 94,2 & 46,90 & $-50,21 \%$ & & \\
\hline
\end{tabular}

the generation of natives who entered the Social Security records between 1979 and 1982 to have a relatively long labor market history to look at. Focusing first on natives, we observe that there are returns to education at labor market entry. For instance, when they first enter the labor market natives working in jobs requiring no high-school degree earn 15 percent lower wages than those working in jobs requiring a high-school degree, and these workers earn 19 percent less than those working in jobs requiring a college degree. Moreover, natives' returns to education grow faster the higher their human capital. Natives working in jobs requiring no degree see their wages increase by 
21 percent over a decade, compared to the 36 percent increase experienced by those in jobs requiring a high-school degree, or the 51 percent increase experienced by those in jobs requiring a college degree.

Focusing now on the wage penalty immigrants face at arrival (relative to similar natives), we observe that the initial penalty that migrants face increases with skill level. Estimates from column 3 reveal that while low-skilled migrants arriving in the 1991-1995 earn 35 percent lower wages than similar natives at arrival, medium- and high-skilled migrants earn 39 and 41 percent lower wages than their native counterparts, respectively. Similar findings emerge for the cohort of migrants arriving in the 2001-2005 period. At arrival, low-skilled migrants earn 27 percent lower wages than similar natives, while medium- and high-skilled migrants earn 36 and 47 percent lower wages than their native counterparts. Moreover, estimates from Table 1 also reveal that the immigrant wage penalty only decreases over time for low-skilled migrants. In contrast, it increases with time in Spain for medium- and high-skilled migrants. For instance among high-skilled migrants arriving in the 1991-1995 period see their median wage penalty increased from 41 percent in 1991 to 50 percent ten year later.

Table 2 presents estimates from a log wage equation that controls for experience in Spain and abroad, immigrant dummy, years since migration and its squared, and region dummies. As identification of this equation is not possible because of confounding effects between experience (which is much correlated with age), birth cohorts and time effects (Deaton and Paxson, 1994), we restrict time-dependent shocks to be identical to the NAIRU (see Beaudry and Lemieux, 1999, and Izquierdo et al., 2009).

The analysis is done for the three different groups of workers, based on their skill level. The immigrant dummy shows the wage differential between immigrants and their native counterparts at arrival. Upon arrival, we observe that the wage differential is larger the higher the skill-level required for a job. For example, we observe that, at arrival, low-skilled immigrants earn 24 percentage points lower wages than their native counterparts. In contrast, medium- and high-skilled immigrants earn 36 and 41 percentage points lower wages than their native counterparts, respectively.

The coefficients from the "years since arrival" dummies show how the immigrantnatives wage differential decreases over time. After 10 years in the country, the wage gap has narrowed by 12 percentage points for low-skilled workers and 14 percentage points for medium-skilled workers. While there is practically no difference in wage assimilation between low- and medium-skilled workers over time, high-skilled workers experience a higher wage convergence as their wage gap narrows 27 percentage points after a decade in the country. In addition, we find that full assimilation does not occur, as in Izquierdo et al. 2009, as a 12 percentage points wage differential remains for workers in jobs requiring no degree, 22 percentage points remains for workers in jobs requiring a high-school degree and 14 percentage points remain for workers in jobs requiring a college degree. After the first ten years in the country, the coefficients on the "years since migration" dummies either remain constant (for high-skilled workers) or begin to decrease (for medium- and low-skilled ones).

The coefficients on the cohort of arrival dummies also reveal an interesting result. There has been a quality upgrade since 1996 among low-skilled immigrant workers, but a quality downgrade among the high-skilled immigrant cohorts arriving from 1991 
Table $\mathbf{2}$ Wage equation estimations at percentile $\mathbf{5 0}$ males by education level, longitudinal 2008 MCVL

\begin{tabular}{|c|c|c|c|}
\hline & High school dropouts & High school graduates & University \\
\hline \multirow[t]{2}{*}{ Birth cohort < = 1934} & $0.111^{* * *}$ & $0.359^{* * *}$ & 0.039 \\
\hline & $(0.031)$ & $(0.050)$ & $(0.030)$ \\
\hline \multirow[t]{2}{*}{ Birth cohort 1935-1944 } & $0.171^{* * *}$ & $0.142^{* * *}$ & $0.082^{* * *}$ \\
\hline & $(0.008)$ & $(0.014)$ & $(0.007)$ \\
\hline \multirow[t]{2}{*}{ Birth cohort 1945-1954 } & $0.333^{* * *}$ & $0.234^{* * *}$ & $0.177^{* * *}$ \\
\hline & $(0.003)$ & $(0.005)$ & $(0.002)$ \\
\hline \multirow[t]{2}{*}{ Birth cohort 1955-1964 } & $0.174^{* * *}$ & $0.084^{* * *}$ & $0.168^{* * *}$ \\
\hline & $(0.002)$ & $(0.003)$ & $(0.001)$ \\
\hline \multirow[t]{2}{*}{ Birth cohort 1965-1974 } & $0.046^{* * *}$ & $0.012^{* * *}$ & $0.113^{* * *}$ \\
\hline & $(0.001)$ & $(0.002)$ & $(0.001)$ \\
\hline \multirow[t]{2}{*}{ Nairu } & $-0.034^{* * *}$ & $-0.014^{* * *}$ & $-0.005^{* * *}$ \\
\hline & $(0.000)$ & $(0.001)$ & $(0.000)$ \\
\hline \multirow[t]{2}{*}{ Total experience } & $0.067^{* * *}$ & $0.057^{* * *}$ & $0.095^{* * *}$ \\
\hline & $(0.001)$ & $(0.002)$ & $(0.001)$ \\
\hline \multirow[t]{2}{*}{ Total experience2 } & $-0.008^{* * *}$ & $-0.004^{* * *}$ & $-0.006^{* * *}$ \\
\hline & $(0.000)$ & $(0.000)$ & $(0.000)$ \\
\hline \multirow[t]{2}{*}{ Total experience 3} & $0.000^{* * *}$ & $0.000^{* * *}$ & $0.000^{* * *}$ \\
\hline & $(0.000)$ & $(0.000)$ & $(0.000)$ \\
\hline \multirow[t]{2}{*}{ Total experience 4} & $-0.000^{* * *}$ & $-0.000^{* * *}$ & $-0.000^{* * *}$ \\
\hline & $(0.000)$ & $(0.000)$ & $(0.000)$ \\
\hline \multirow[t]{2}{*}{ non EU-15 } & $-0.236^{* * *}$ & $-0.362^{* * *}$ & $-0.408^{* * *}$ \\
\hline & $(0.019)$ & $(0.053)$ & $(0.022)$ \\
\hline \multirow[t]{2}{*}{ Years since migration 1_2 } & $0.046^{* * *}$ & $0.064^{* * *}$ & $0.088^{* * *}$ \\
\hline & $(0.007)$ & $(0.013)$ & $(0.008)$ \\
\hline \multirow[t]{2}{*}{ Years since migration 3_4 } & $0.088^{* * *}$ & $0.103^{* * *}$ & $0.152^{* * *}$ \\
\hline & $(0.007)$ & $(0.015)$ & $(0.009)$ \\
\hline \multirow[t]{2}{*}{ Years since migration 5_6 } & $0.074^{* * *}$ & $0.097^{* * *}$ & $0.194^{* * *}$ \\
\hline & $(0.009)$ & $(0.018)$ & $(0.011)$ \\
\hline \multirow[t]{2}{*}{ Years since migration 7_8 } & $0.109^{* * *}$ & $0.121^{* * *}$ & $0.201^{* * *}$ \\
\hline & $(0.011)$ & $(0.022)$ & $(0.014)$ \\
\hline \multirow[t]{2}{*}{ Years since migration 9_10 } & $0.119^{* * *}$ & $0.144^{* * *}$ & $0.271^{* * *}$ \\
\hline & $(0.016)$ & $(0.033)$ & $(0.020)$ \\
\hline \multirow[t]{2}{*}{ Years since migration 11_12 } & $0.091^{* * *}$ & $0.111^{* *}$ & $0.272^{* * *}$ \\
\hline & $(0.022)$ & $(0.048)$ & $(0.026)$ \\
\hline More than 13 years since & $0.058^{* * *}$ & $0.107^{* *}$ & $0.268^{* * *}$ \\
\hline migration & $(0.021)$ & $(0.048)$ & $(0.022)$ \\
\hline \multirow[t]{2}{*}{ Experience abroad from 5-9 } & $-0.092^{* * *}$ & -0.058 & $-0.121^{* * *}$ \\
\hline & $(0.007)$ & $(0.037)$ & $(0.008)$ \\
\hline \multirow[t]{2}{*}{ Experience abroad from 10-14 } & $-0.123^{* * *}$ & $-0.125^{* * *}$ & $-0.203^{* * *}$ \\
\hline & $(0.006)$ & $(0.037)$ & $(0.009)$ \\
\hline \multirow[t]{2}{*}{ Experience abroad, from 15-19 } & $-0.179^{* * *}$ & $-0.235^{* * *}$ & $-0.186^{* * *}$ \\
\hline & $(0.007)$ & $(0.037)$ & $(0.010)$ \\
\hline More than 25 years of & $-0.215^{* * *}$ & $-0.302^{* * *}$ & $-0.262^{* * *}$ \\
\hline experience abroad & $(0.009)$ & $(0.039)$ & $(0.014)$ \\
\hline \multirow[t]{2}{*}{ Arrival 1983-1985 } & -0.034 & -0.133 & $-0.449^{* * *}$ \\
\hline & $(0.048)$ & $(0.115)$ & $(0.063)$ \\
\hline
\end{tabular}


Table $\mathbf{2}$ Wage equation estimations at percentile $\mathbf{5 0}$ males by education level, longitudinal 2008 MCVL (Continued)

\begin{tabular}{|c|c|c|c|}
\hline Arrival 1986-1990 & 0.025 & -0.077 & $0.333^{* * *}$ \\
\hline & $(0.024)$ & $(0.049)$ & $(0.024)$ \\
\hline \multirow[t]{2}{*}{ Arrival 1991-1995 } & -0.023 & $-0.144^{* * *}$ & $-0.167^{* * *}$ \\
\hline & $(0.020)$ & $(0.041)$ & $(0.021)$ \\
\hline \multirow[t]{2}{*}{ Arrival 1996-2000 } & $0.042^{* *}$ & -0.029 & $-0.165^{* * *}$ \\
\hline & $(0.018)$ & $(0.037)$ & $(0.020)$ \\
\hline \multirow[t]{2}{*}{ Arrival 2001-2005 } & $0.052^{* * *}$ & -0.005 & $-0.141^{* * *}$ \\
\hline & $(0.018)$ & $(0.036)$ & $(0.020)$ \\
\hline \multirow[t]{2}{*}{ Arrival >2005 } & $0.112^{* * *}$ & 0.038 & -0.002 \\
\hline & $(0.020)$ & $(0.039)$ & $(0.021)$ \\
\hline \multirow[t]{2}{*}{ Constant } & $8.668^{* * *}$ & $8.438^{* * *}$ & $8.473^{* * *}$ \\
\hline & $(0.004)$ & $(0.007)$ & $(0.004)$ \\
\hline$R 2$ & 0,0342 & 0,0637 & 0,1074 \\
\hline Sample size & $2,158,016$ & 844,580 & 343,590 \\
\hline \multicolumn{4}{|c|}{$\begin{array}{l}\text { Note: Dependent variable: logarithm of daily wages. Regressions are estimated pooling natives and immigrants coming } \\
\text { from countries outside the EU-15. In addition, regressions include experience in Spain and abroad, the NAIRU (HP filter } \\
\text { on the original unemployment) and region dummies. See Appendix Table A.1 for complete list of coefficients. Restricting } \\
\text { time effects to certain macroeconomic variables has been widely used in the literature (see Beaudry and Lemieux, 1999). } \\
{ }_{* * *} p<0.01,{ }^{* *} p<0.05,{ }^{*} p<0.1 \text {. }\end{array}$} \\
\hline
\end{tabular}

to 2005 in Spain. No changes in cohort quality are observed among medium-skilled workers, except for the 1991-1995 cohort, which was of higher quality.

Figure 2 plots the immigrants-natives wage differential for a representative cohort of workers born between 1975 and 1984. Immigrants in Figure 2 arrived in Spain between 1996 and 2000 and had less than five years of experience abroad.

Figure 2 shows that at arrival high-skilled migrants earn 50 percentage points less than similar natives and that this differential decreases 40 percent to 30 percentage points ten year later. Among medium-skilled workers, the differential upon arrival is 45 percentage points and it decreases 22 percent to 35 percentage points a decade later. Among low-skilled workers, the differential upon arrival is the smallest (21 percentage points) and it drops 33 percent to 14 percentage points ten years later. Thus, although the rate at which the gap narrows is greatest for the college educated, because the wage gap upon arrival is larger the higher the skill required, ten years after arrival lower skilled immigrants are faring relatively better than higher skilled ones when compared to similar natives. Moreover, it is also interesting to note that, for this cohort, the rate of convergence is lower for medium- than low-skilled workers, suggesting that having a high-school degree does not buy migrants much in terms of wage assimilation (relative to their native counterparts) in Spain.

\section{Possible explanations for the Spanish results}

We find, on average, practically no difference in wage assimilation between immigrants in jobs requiring a high-school degree and those that do not. Similarly, we find that having a high-school degree does not give immigrants an advantage in terms of which occupations they work upon arrival or later on (relative to their native counterparts). These findings contrasts with those from countries with dense migratory traditions. In this section, we discuss possible explanations for these results and contrast them with what is known about immigrants' assimilation in Spain. 


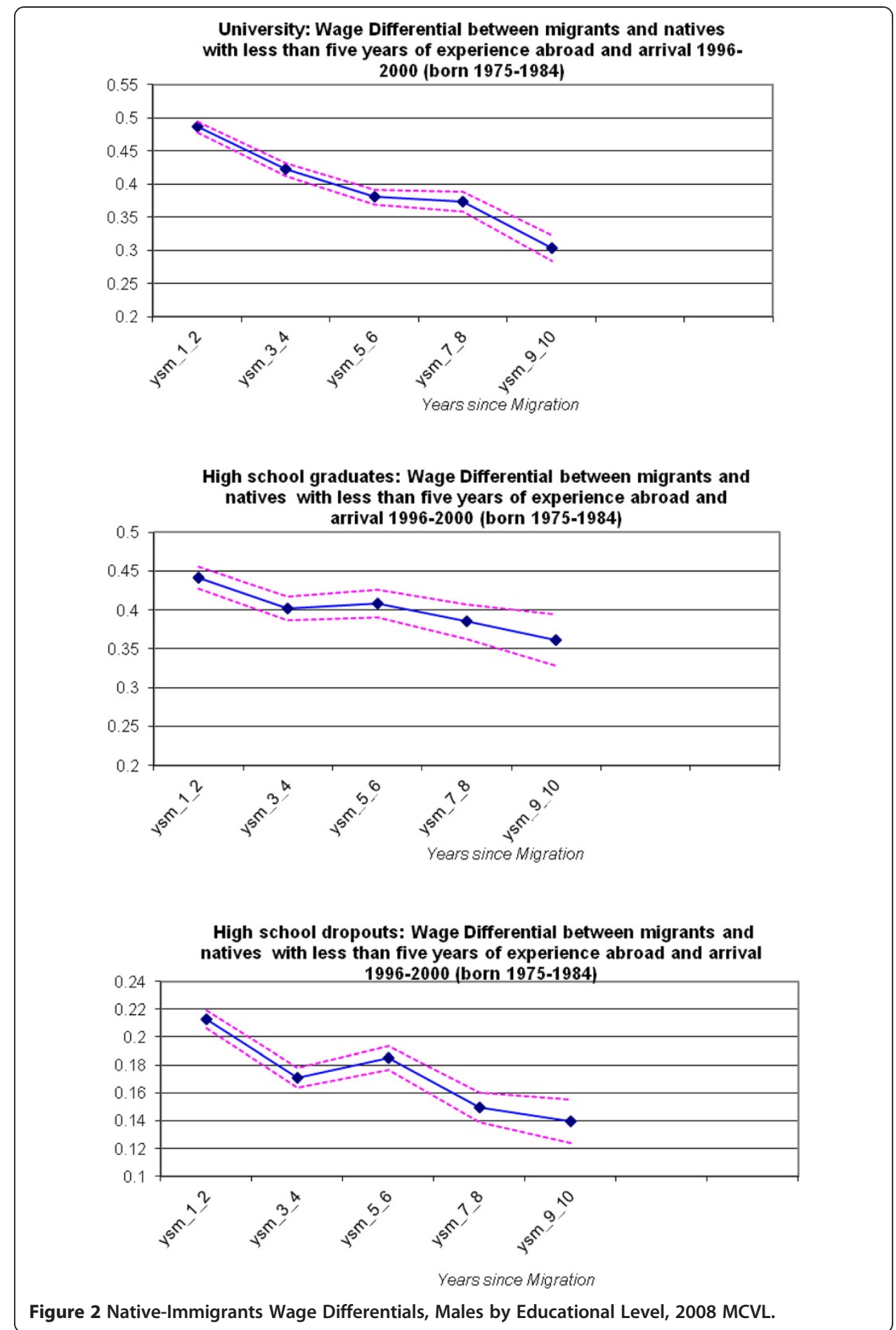

The first explanation for these results is that the assimilation process of immigrants reflects the structural nature of the Spanish economic growth in the last decade, combined with the weak governmental capacity of regulate immigrant inflows. For the last decade, Spain has generated a much higher proportion of low-qualified jobs in the construction sectors, food preparation and serving, and domestic services. Given that immigrants' reservation wage is much lower than that of natives-no matter their 
educational level, especially if they are illegal immigrants, as most of them are when they first enter the country-, and that most of them come to Spain to work, it ought not to be a surprise that they present high levels of segregation in these four lowskilled sectors, as several authors have found (Sanromá et al. 2009; and González and Ortega, 2010). According to the skill-job matching theory, if most immigrants end up in these low-skilled occupations, it is unclear whether their human capital would be useful as it is often tied to a particular occupation and its transferability across occupations is limited. In addition, because little or no on-the-job training takes place in these very-low-qualified jobs, it is unclear that higher educated immigrants permanently working in such jobs would assimilate faster than the rest of immigrants. This is so, because assimilation requires learning, and this is not automatically given through an educational degree. Moreover, upward occupational assimilation is likely to be difficult as long as immigrants' status remains illegal (or working in the informal sector).

On the other hand, if the transferability of human capital acquired abroad is imperfectly portable, the higher the homeland education the greater the gap between the native and the immigrant's human capital, making assimilation more difficult among the more educated immigrants ${ }^{17}$. As human capital acquired abroad becomes more portable (because of its proximity), we ought to expect that this lack of convergence between immigrants and natives with a university degree fades away.

Alternatively, in an economy with a segmented labor market and with a large informal sector, such as the Spanish economy, one would also expect for immigrants to assimilate faster if they are low-skilled ${ }^{18}$. Under such view, workers with little access to the primary labor market enter the secondary sector (or the informal sector) while queuing for good wage and salary jobs in the formal sector. Since more vulnerable groups of native workers, such as low-skilled workers, youth, and women, tend to be concentrated in the secondary labor market and the informal sector-Kahn, 2007; and Estrada et al., 2009, among others-, converging towards their occupational distribution ought to be relatively easier for low-skilled immigrants than the convergence process of high-skilled immigrants towards the occupational distribution of high-skilled natives, who are likely to be concentrated in the primary labor market. Indeed, Fernández and Ortega, 2008, do find that the incidence of temporary contracts is much higher for newly arrived male immigrants than for comparable natives, while it is very similar for newly arrived female immigrants and their native counterparts.

An alternative and complementary explanation for this result is the need for certification. Several occupations that require high levels of education also require certification in the destination country. This is clearly the case in the Spanish labor market, and not only for architects, physicians, or lawyers, but also for electricians, plumbers, and the like. While certification may have a basis in country specific required skills, it also may have elements of discrimination and job protection.

Yet another explanation is that immigrants may affect the labor market decisions of natives with different skills through the presence of complementarities. In Spain, Farré et al., 2011, find an important positive effect of immigration on the labor supply of highly skilled native women. In particular, these authors find that the recent immigration flow can account for one third of the increase in the employment rate of collegeeducated women during the last decade. The explanation for this positive effect is that immigration has increased the local supply and decrease the price of market-provided 
services that are close substitutes with housework (such as cleaning, cooking or child and elderly care). As a result, women who can afford to purchase these services may be able to shift time from housework toward market work.

Similarly our findings are consistent with a shift towards less manual jobs among the native male population compared to a shift in the opposite direction for male immigrants, providing some evidence that these two populations have become more complementary over time. Several recent papers have highlighted that native and immigrant workers of similar educational attainment specialize in different occupations and therefore do not compete for the same jobs, explaining the small effect the inflows of immigrants on the wages of the less-educated natives in the U.S. (Ottaviano and Peri, 2006) as well as in Spain (Carrasco et al., 2008b). For instance, Peri and Sparber, 2008, find evidence of imperfect substitutability between natives and immigrants of similar educational attainment in the U.S. Dustmann, et al. 2008, also show that natives and immigrants in the U.K. of comparable skills do not compete for the same jobs, and Carrasco et al., 2008b, and Amuedo-Dorantes and de la Rica, 2011, find evidence of immigrants and natives being imperfect substitutes within skill categories in Spain. Perhaps more importantly, Amuedo-Dorantes and de la Rica, 2011, find that the impact of immigration on the relative task supply of natives is twice as great in Spain as in the United States. Moreover, these authors find that foreign-born workers only seem to have a significant impact on the employment pattern of native workers of the same sex. More precisely, foreign-born male (female) workers do not appear to be perfect substitutes of similarly skilled native male (female) workers, which may help explain the null or small impacts of immigration on native employment and wages. Instead, immigration appears to have affected the task specialization and occupational distribution of natives of the same gender.

Finally, prejudicial attitudes leading to discriminatory behavior could also produce lower labor market attainments for member of visible minority groups, if such discrimination takes the form of refusing to hire members of the minority group for certain occupations for which they are qualified to work in. Since the degree of prejudice is assumed to be a function of social and cultural distance, this view would predict that economic discrimination would increase as a function of distance.

\section{Consequences and policy recommendations}

The study of the assimilation process of recently arrived immigrants in Spain by skill level reveals two interesting novel results. First, using LFS data, we find that upon arrival all immigrants--including those with a college degree--are over-represented in the "non-qualified" category, which includes jobs such as, janitors, entry position in construction work, non-qualified laborers, among others. After 3 to 4 years after arrival, immigrants begin to shift out of "non-qualified" jobs towards "qualified blue-collar" occupations (for males) and "white-collar" occupations (for females). However, we find that having a high-school degree does not give immigrants an advantage in terms of which occupations they work upon arrival or later on (relative to their native counterparts).

Second, using an alternative longitudinal data set from Social Security records, we analyze immigrants' wage assimilation (relative to similar natives) by skill-level. And we find that, upon arrival, the wage differential is larger the higher the skill-level required for a job. For example, we observe that, at arrival, low-skilled immigrants earn 24 percentage 
points lower wages than their native counterparts. In contrast, medium- and high-skilled immigrants earn 36 and 41 percentage points lower wages than their native counterparts, respectively. Moreover, we find that although wage assimilation (compared to similar natives) is largest for immigrants in jobs requiring a college degree, there is practically no difference in wage assimilation between immigrants in jobs requiring a high-school degree and those that do not. Finally, we find that 10 years upon entry the formal labor market, full assimilation of wages does not take place as a 12 percentage points wage differential remains for workers in jobs requiring no degree, 22 percentage points remains for workers in jobs requiring a high-school degree and 14 percentage points remain for workers in jobs requiring a college degree.

As we have explained, it is likely that the weak governmental capacity to regulate immigrant inflows combined with the construction, tourism, and personal services growth experienced by Spanish economy in the last decade explains the over-representation of immigrants in low-qualified occupations (regardless of their educational level) and the lack of upward occupational mobility. In addition, the large informal sector, the striking segmentation of the Spanish labor market, the need for certification, the imperfect transferability of human capital acquired abroad, and discrimination are likely to be part of the story to a certain extent. Unfortunately, while a combination of the above explanations may apply, without further data, we cannot differentiate between these explanations and their relative importance.

Regardless of the explanation, several policy implications emerge. First, there is an urgent need to properly design immigration policies such that they improve the selection of immigrants who best match Spanish labor market conditions to avoid waste and erosion of human capital. Moreover, it is most important to regulate these immigration policies and insure that they are correctly implemented. Within this context, the promotion of circular migration schemes, which allow the systematic and regular movement of migrants typically seeking work between their homelands and foreign countries, might be particularly useful especially among low-skilled workers. According to Constant et al. 2011, circular migration is widely perceived as a potential "win-winwin situation" that can help to relax the potential social tension from migration for at least the following three reasons. First, circular migrants take advantage of better employment and payment opportunities in the host country; they optimize and reoptimize their income, savings and assets strategies, and thus improve their economic, social and personal situation at each stage. Second, for receiving countries circular migration is desirable because it may help to plug labor market shortages by matching excessive labor demand in host countries and excessive labor supply in sending countries. And third, sending countries benefit from remittances sent by migrants abroad, and if the better skilled return, they are highly valuable since they transfer knowledge acquired abroad and bring back new ideas. As the German guests workers experience from the late 1950s and 1960s and the Bracero US program for Mexicans during the early 1960s have shown, immigration restrictions and enforced return migration often result in an unintended increase of (illegal) immigrants. In contrast, free mobility and the option to return to the hosting country would encourage circularity because immigrants who belong to these programs can return to the host country whenever desired, they can search for and accept the best jobs offered - in the home or the host country (Constant et al. 2011). 
Second, the legalization process of those illegal immigrants already in the country must be clarified as their illegal status puts them in the most vulnerable situations and precludes them from equity and anti-bias rights. Third, governments at all levels must be actively involved in assisting immigrants to interpret their foreign credentials for employers, educating employers about immigrants' potential value in the Spanish labor market, and facilitating the acquisition of Spanish credentials among immigrants lacking them. This implies accelerating the process for converting foreign credentials into their Spanish equivalent. It also implies improving the information on which credentials and from which universities and colleges abroad are equivalent to Spanish degrees and which are not (that is, establishing some type of ranking). Fourth, employment equity policies and anti-bias legislation are key tools to reduce prejudice and shift values ${ }^{19}$. Most of these efforts ought to be emphasized for immigrant women, as they seem to suffer greater segregation into the bad and precarious jobs (and practically experience no upward mobility). Moreover, the fact that many employment decisions of migrant women are strongly influenced by personal, cultural and social preferences need to be carefully taken into account in the design of such policies. Fifth, policy proposals aiming at reducing the informal sector and adding labor market flexibility, on the one hand, and changing the structural nature of the Spanish economy, on the other, will most likely enhance an efficient allocation of labor, and improve economic growth, respectively.

\section{Endnotes}

${ }^{1}$ Countries with a long tradition of receiving immigrants include: Australia (Chiswick and Miller, 1995); Canada (Baker and Benjamin, 1994; and Hum and Simpson, 2000, Hum and Simpson, 2004); Germany (Schmidt, 1992; and Constant and Massey, 2005); Israel (Flug, et al., 1992; Friedberg, 2001; and Eckstein and Weiss, 2004, among others); and the United States ( see Card, 2005 for literature review).

${ }^{2}$ As we explain later, because the ethnic composition of immigrants has shifted drastically over the last decade in Spain, their findings are not necessarily transferable to the current situation.

${ }^{3}$ Green (1999) excludes women from his analysis.

${ }^{4}$ A similar finding is observed in Sweden (Duvander, 2001).

${ }^{5}$ To have the legal status, immigrants were required to acquire a work and residency permit that restricted them to work in a particular activity and geographic area only for a year. In addition, immigrants were not granted any social benefit despite paying social security taxes when employed.

${ }^{6}$ For instance in the 2000 amnesty to become legal aliens, immigrants had to provide proof of one of the following: (i) residence since June 1st, 1999; (ii) having held a work permit any time during the three-year period preceding February 1st, 2000; (iii) being denied asylum before February 2000; (iv) having applied for any type of residence permit before March 30th, 2000; or (v) family ties to legal residents or to individuals in any of the previous categories.

${ }^{7}$ We exclude younger individuals because we want to focus on individuals who are likely headed for the labor force in the near future and to avoid issues of noncomparability of the experiences of young immigrants who received part of their basic education in Spain and those who arrived at older ages. This restriction criteria is common in the literature, see Boyd, 1985; Kossoudji, 1989; and Green, 1999, among others. 
${ }^{8}$ As the vast majority of immigrant flows has taken place from the late nineties onwards, the immigrant samples are restricted to those entering in 1990 and after (as in AmuedoDorantes and de la Rica, 2007, and Gonzalez and Ortega, 2008, among others).

${ }^{9}$ Results available from the author upon request.

${ }^{10}$ For native-born individuals, the person is living in Madrid, aged 35 to 39 years old, currently married. For immigrants, that person is from Latin America and arrived in Spain in 2002.

${ }^{11}$ We ran separate multinomial logit models (MNL) for immigrants and natives because many studies have pointed out the importance of taking into account differences between immigrants and natives in their returns to human capital, and labor market experience (Friedberg, 2001; and Fernández and Ortega, 2009). The MNL model permits estimation of the effects of various characteristics of an individual on his choice from among a set of alternatives that do not have a natural ordering, occupations in this case. Notice that the MNL approach is not uncommon when analyzing a model of occupational choice (see Green, 1999, Weiss et al., 2003; Wanner and Ambrose, 2003; among others). Further details on the sample used and the methodology can be found in Alcobendas et al., 2012.

${ }^{12}$ Unfortunately our data do not identify in which country the educational degree was obtained, precluding us from such type of analysis. Nonetheless, Sanromá et al. 2009, estimate that immigrants in Spain acquire the bulk of their human capital in their home country (10.95 of their 11.1 years of education, on average, corresponds to their home country), and they find that only $5.5 \%$ of immigrants get some schooling in Spain.

${ }^{13}$ While high-school dropout natives have a fitted probability of being in either category of about $8 \%$ and $9 \%$, respectively; for high-school graduates these fitted probabilities increase to $13 \%$ and $16 \%$, respectively.

${ }^{14}$ Notice that the flow out of the "professional" category reflects natives moving in towards that category over time.

${ }^{15}$ Spanish female participation is in the order of 65 percent but drops to $15-20$ percent after the birth of the first child. In contrast with other countries, this low participation rate among Spanish mothers does not increase as the youngest child ages (Nollenberger and Rodríguez-Planas, 2012).

${ }^{16}$ As immigrants have a higher probability of being over-qualified for their jobs than natives, our estimates will be a lower bound on over-education.

${ }^{17}$ Borjas, 1999, develops a human capital model in which the extent to which highskilled immigrants improve their occupational profile is theoretically ambiguous because the benefits from greater "complementarity" between pre- and post-migration human capital may be diluted by the "opportunity costs" of human capital investments through forgone earnings.

${ }^{18}$ The informal sector represents up one fourth of the GDP. Moreover, while two thirds of the jobs in the formal sector are permanent with high-productivity growth, good benefits and chances of promotion; as many as one third of them are temporary jobs with little productivity, high turnover, no benefits or training (see Segura et al., 1991, among others).

${ }^{19}$ Darity and Mason 1998, have shown that in the US anti-discrimination laws have played an important role in reducing discriminatory practices. 


\section{Competing interests}

The IZA Journal of European Labor Studies is committed to the IZA Guiding Principles of Research Integrity. The author declares that she has observed these principles.

\section{Acknowledgements}

I would like to thank Miguel Angel Alcobendas and Raquel Vegas for excellent research assistance. I thank two anonymous referees, and the editor, Klaus F. Zimmermann. All remaining errors are my own. The author acknowledges financial support from the Spanish Ministry of Science and Innovation (grant MICINN ECO2009-11857), and the Generalitat de Catalunya (SGR 2009-57).

Responsible editor: Klaus F. Zimmermann.

Received: 3 May 2012 Accepted: 15 December 2012

Published: 31 December 2012

\section{References}

Alcobendas MA, Rodríguez-Planas N, Vegas R (2012) Wage and Occupational Assimilation by Skill Level. IZA discussion paper No. 6543

Amuedo-Dorantes C, De la Rica S (2005) Immigrants' Responsiveness to Labor Market Conditions and its Implications on Regional Disparities: Evidence from Spain. IZA Discussion Paper No. 1557

Amuedo-Dorantes C, De la Rica S (2007) Labor Market Assimilation in Spain. British J Ind Relat 45(2):257-284, 0007-1080

Amuedo-Dorantes C, De la Rica S (2011) Complements or Substitutes? Task Specialization by Gender and Nativity in Spain". Labour Econ 18(5):697-707

Andrés J (2009) España y los Desequilibrios Globales. In: Libro Electrónico Sociedad Abierta-Fedea: "La Crisis de la Economía Española: lecciones y propuestas", 09/02/2009

Arango J (2004) La inmigración en España a comienzos del siglo XXI. In: Leal J (ed) Informesobre la situación demográfica en España. Fundación Abril Martorell, Madrid, pp 161-186

Baker M, Benjamin D (1994) The Performance of Immigrants in the Canadian Labour Market. J Labor Econ 12:369-405

Bauer T, Zimmermann K (1999) Occupational Migration of Ethnic Migrants. IZA Discussion Paper No. 58

Beach CM, Worswick C (1993) Is There a Double-Negative Effect on the Earnings of Immigrant Women? Can Public Policy 19:36-53

Beaudry P, Lemieux T (1999) Evolution of the female labour force participation rate in Canada, 1976-1994. In: Mimeo Centre Interuniversitaire de Reserche en Analyse des Organisations.

Borjas G (1992) National Origin and the Skills of Immigrants. In: Borjas GJ, Freeman RB (eds) Immigration and the Work Force. The University of Chicago Press, Chicago

Borjas G (1999) The Economic Analysis of Immigration. In: Ashenfelter O, Card D (eds) Handbook of Labor Economics, vol. 3. Elsevier Science, North-Holland, Netherlands, pp 1697-1999

Boyd M (1984) At a Disadvantage: The Occupational Attainments of Foreign-Born Women in Canada. Int Migr Rev 18:1091-1119

Boyd M (1985) Immigration and Occupational Attainment in Canada. In: Boyd M, Goyder J, Jones FE, McRoberts HA, Pineo PC, Porter J (eds) Ascription and Achievement: Studies in Mobility and Status Attainment in Canada. Carleton University Press, Ottawa, pp 383-445

Boyd M (1992) Gender, Visible Minority, and Immigrant Earnings Inequality: Reassessing an Employment Equity Promise. In: Satzewich V (ed) Deconstructing a Nation: Immigration, Multiculturalism, and Racism in'90s Canada. Fernwood Publishing, Halifax, pp 279-321

Castles S, Miller MJ (2003) The Age of Migration, International Population Movements in the Modern World. Palgrave, Hampshire and New York

Card D, Dinardo J (2000) Do Immigrant Inflows Lead to Native Outflows? Am Econ Rev 90

Card D (2005) Is the New Immigration Really So Bad? Econ J 115

Carrasco R, Jimeno JF, Ortega AC (2008a) "The Effect of Immigration on the Employment Opportunities of Native-Born Workers: Some Evidence for Spain. J Popul Econ 21:627-648

Carrasco R, Jimeno JF, Ortega AC (2008b) The Impact of Immigration on the Wage Structure: Spain 1995-2002. In: Universidad Carlos III working paper 08-16

Chiswick B, Miller P (1995) The Endogeneity Between Language and Earnings: International Analyses. J Labor Econ 13(2):246-288

Cobb-Clark D (1993) Immigrant Selectivity and Wages: The Evidence for Women. Am Econ Rev 83(4):986-93

Constant A, Massey D (2002) Self-selection, earnings and out-migration: a longitudinal study of immigrants to Germany. J Popul Econ 16:631-653

Constant A, Massey D (2005) "Labor Market Segmentation and the Earnings of German Guest workers.". Popul Res Policy Rev 24(6):5-30

Constant A, Nottmeyer O, Zimmermann K (2011) he Economics of Circular Migration. In: IZA Discussion Paper 6940 Forthcoming 2013 in Edward Elgar International Handbook of Economics of Migration

Cuñat V, Garicano L (2009) Para Cuando la Reestructuración del Sistema Financiero Español. Tribuna, 13/09/2009), El País

De la Rica S (2009) The Experience of Spain with the Inflows of New Labor Migration. In: Kahanec M, Zimmermann KF (eds) EU Labor Markets after Post-Enlargement Migration, Berlin, pp 131-144

Darity WA Jr, Mason PL (1998) Evidence on Discrimination in Employment: Codes of Color, Codes of Gender,". J Econ Perspect 12(2):63-90, Spring

Dolado J, Vázquez P (2007) Los Efectos Económicos y las Políticas de la Inmigración: Panorámica y Reflexiones. Fedea Working Paper

Dustmann C, Frattini T, Preston I (2008) The Effect of Immigration along the Distribution of Wages. CReAM Discussion Paper \# 03/08 
Duvander A (2001) Do Country-Specific Skills Lead to Improved Labor Market Positions?: An Analysis of Unemployment and Labor Market Returns to Education among Immigrants in Sweden. Work Occup 28:210

Eckstein Z, Weiss Y (2004) "On the Wage Growth of Immigrants: Israel 1990-2000. J Eur Econ Assoc :665-695

Edin PA, LaLonde R, Aslund O (2000) Emigration of immigrants and measures of immigrant assimilation: evidence from Sweden. Swed Econ Policy Rev 7:163-204

Estrada A, Izquierdo M, Lacuesta A (2009) Funcionamiento del Mercado de Trabajo y el Aumento del Paro en España. 102 Boletín Económico, Julio-Agosto 2009, Banco de España

Farré L, González L, Ortega F (2011) Immigration, Family Responsibilities and the Labor Supply of Skilled Native Women. BE J Econ Anal Policy (Contributions) 11 (issue 1):1-46

Fernández C, Ortega C (2008) Labor market assimilation of immigrants in Spain: Employment at the Expense of Bad Job-Matches? Span Econ Rev 10(2):83-107

Ferrera M (1996) The "Southern Model" of Welfare in Social Europe. J Eur Soc Policy 6(1):17-37

Flaquer L (2000) Family Policy and Welfare State in Southern Europe. Institut de Ciències Polítiques I Socials, WP No, 185

Flug K, Kasir N, Gur O (1992) The Absorption of Soviet Immigrants into the Labor Market from 1990 Onwards: Aspects of Occupational Substitution and Retention. In: Bank of Israel Discussion Paper no. 9213. Central Bank of Israel, Jerusalem, April

Friedberg R (2000) You Can't Take it with You? Immigrants Assimilation and the Portability of Human Capital: Evidence from Israel. J Labor Econ 18(2):221-251

Garicano L (2008) La Transición Económica Pendiente. en Expansión el 05-12-2008

González L, Ortega F (2010) How do very open economies adjust to large immigration flows? Evidence from Spanish regions. Labour Econ

Green D (1999) Immigrant Occupational Attainment: Assimilation and Mobility over Time. J Labor Econ 17(11):49-79

Guillén A (1997) "Welfare State Development in Spain: A Historical and Explanatory Approach" in Mire Florence Conference, Comparing Social Welfare Systems in Southern Europe vol. 3/1997. Paris, Mire, pp 67-91

Hartog J, Zorlu A (2009) How important is homeland education for refugees' economic position in The Netherlands? J Popul Econ 22(1):219-246

Hum D, Simpson W (2000) Closing the Gap: Economic Assimilation of Canadian Immigrants Reconsidered. J IntMigrlntegr 1:427-441

Izquierdo M, Lacuesta A, Vegas R (2009) Assimilation of Immigrants in Spain: a Longitudinal Analysis. Labour Econ Kossoudji S (1989) Immigrant Worker Assimilation: Is It a Labor Market Phenomenon? J Hum Resour 24(3):494-527, Summer Long JE (1980) The Effect of Americanization on Earnings: Some Evidence for Women. J Polit Econ 88(3):620-29 Lubotsky D (2007) Chutes or ladders? A longitudinal analysis of immigrant earnings. J Pol Econ 115:820-867

Martin P, Abella M, Kuptsch C (2006) Managing Labor Migration in the Twenty-first Century. Yale University Press, New Haven and London

Nollenberger N, Rodríguez-Planas N (2012) Childcare, Maternal Employment, and Persistence: A Natural Experiment from Spain. IZA Discussion Paper n. 5888

Ozden C, Neagu IC (2007) immigrant Women's Participation and Performance in the US Labor Market. In: The International Migration of Women. World Bank Research Program on Internation Migration and Development

Ottaviano G, Peri G (2006) Rethinking the Gains from Immigration on Wages. NBER Working Paper \# 12497

Peri G, Sparber C (2008) Task Specialization, Immigration and Wages. NBER Discussion Paper \# $02 / 08$

Reher D, Silvestre J (2009) Internal Migration Patterns of Foreign-Born Immigrants in a Country of Recent MassMigration: Evidence from New Micro Data for Spain. Int Migr Rev 43(4):815-849, (Winter 2009

Rodríguez-Planas N (2012) Determinants of Immigrant's Cash-Welfare Benefit Intake in Spain. Int J Manpow

Sanromá E, Ramos R, Simó H (2009) Immigrant Wages in the Spanish Labour Market: Does the Origin of Human Capital Matter?. IZA Discussion Paper No. 4157

Segura JF, Toharia L, Bentolila S (1991) Análisis de la Contratación Temporal enEspaña. Ministerio de Trabajo y Seguridad Social, Centro de Publicaciones

Schmidt C (1992) Country-of-Origin Differences in the Earnings of German Immigrants. Universität München Discussion Paper $92-29$

Schoeni RF (1998) Labor Market Assimilation of Immigrant Women. Ind Labor Relat Rev 51(3):483-504

Solé C (2004) Immigration Policies in Southern Europe. J Ethn Migr Stud 30(6):1209-1221

Toussaint-Comean M (2006) The Occupational Assimilation of Hispanic Immigrants in the U.S.: Evidence from Panel Data. Int Migr Rev 40(3):508-536.

Wanner R, Ambrose M (2003) Trends in the Occupational and Earnings Attainments of Women Immigrants to Canada, 1971-1996. Can Stud Popul 30(2):355-388

Weiss Y, Sauer R, Gotlibovski M (2003) Immigration, Search and Loss of Skill. J Lab Econ 21:3

doi:10.1186/2193-9012-1-8

Cite this article as: Rodríguez-Planas: Wage and occupational assimilation by skill level: migration policy lessons from Spain. IZA Journal of European Labor Studies 2012 1:8. 